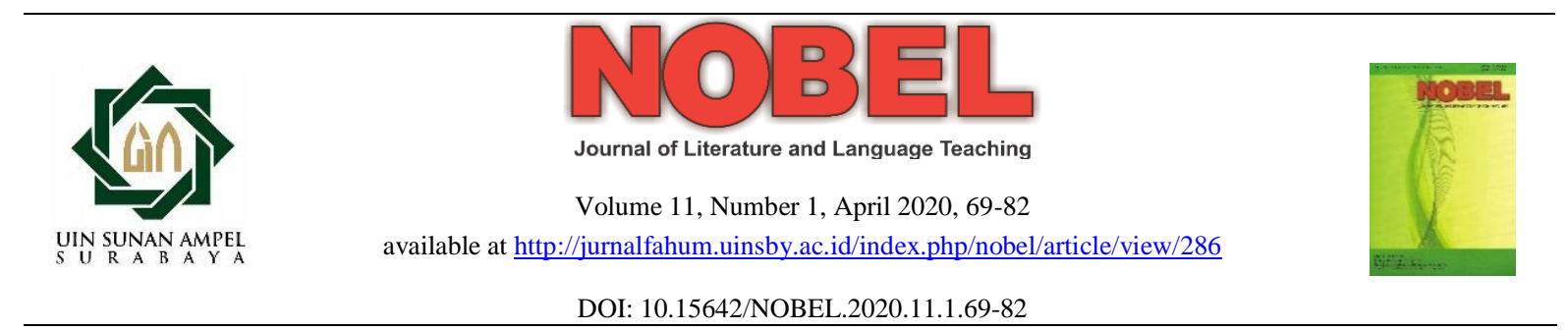

\title{
THE PRESENCE OF PORTUGUESE AND INDONESIA IN TIMOR LESTE AS DEPICTED BY AUSTRALIAN AND BRITISH BROADCASTING CORPORATION: CDA PERSPECTIVE
}

\section{Supeno $^{\bowtie}$}

Universitas Wijaya Kusuma Surabaya (UWKS), Jalan Dukuh Kupang XXV/54 Surabaya, Indonesia 60225

\begin{tabular}{ll}
\hline $\begin{array}{l}\text { Article Info } \\
\begin{array}{l}\text { Article History: } \\
\text { Received February 2020 } \\
\text { Accepted March 2020 } \\
\text { Published April 2020 }\end{array}\end{array}$ & $\begin{array}{l}\text { Abstract } \\
\begin{array}{l}\text { Keywords: } \\
\text { lexical choice, massacre, } \\
\text { nominalization, presence }\end{array}\end{array}$ \\
\hline & Corporation (BBC) views Timor Leste during the period of \\
& Portuguese occupation, Indonesia's presence, until the present-day \\
& conditions. Using some van Dijk's models of CDA to examine the \\
& statements to represent its history in some editorials published by \\
& ABC and BBC news resources, the analysis was carried out at the \\
& levels of selected statements with regard to the linguistic features of \\
& lexical choices, nominalization, passivization, and overcompleteness. \\
& The results of the analysis show that the statements constructed by \\
& ABC and BBC's news editorials as the news discourse about the \\
& history of Timor Leste in such relations are discursively biased in \\
& terms of CDA. With various differences in terms of the linguistic \\
& features, the result also in line with the view that both ABC and \\
& BBC's statements are mostly dichotomizing Portuguese into 'Us' \\
& while Indonesia into 'Them' in terms of van Dijk's 'ideological \\
& square'.
\end{tabular}




\section{INTRODUCTION}

Social media - in whatever form they are-play a very important role in the making of the people's viewpoints. Reports of recent events are almost always pictured in social media just within minutes after the events take place. In terms of Critical Discourse Analysis (hereinafter CDA), however, not many people are aware of different ideological stances that are embedded in these editorials. Exploring these ideological stances in the media discourse is currently a very common topic for many research studies in CDA. As Fairclough (1995a, p. 2) states, "the media is an important element within research on contemporary processes of social and cultural change." Similarly, van Dijk (1998, pp. 126-128) argues that news reports signify an established category of media discourse that requires a distinct method of structural analysis.

Although many news writers claim that in the process of news writing one should be as objective as possible, neutrality has always remained a question to discourse analysts. When editors choose a topic, a story, or even a photograph, they consider many factors that are technically called biases (Herman \& Chomsky, 1988, p. 2). In other words, within the process of selection and transformation of news, writing a simple event can be depicted in many different perspectives. It all depends on who the owner of the news resources and how the event is intended to be.

In regards to the process of selection and transformation in media discourse, Wilkins (1997, p. 60), following extensive research on Western Media Discourses, argues that "the images used in the western press compose a selective portrait of reality that resonates with the dominant western ideological perspectives." Tightly related to that, Ferguson (1998, p. 155) describes how events which one may hear or read are indeed 'mediated accounts of what has happened'. In relation to this, Herman and Chomsky (1988, p. 2) maintain that "elite domination of the media and the marginalization of information is done naturally because of the filters that news is subjected too." As such, social media are capable of shaping people's minds, and they can make them to either accept or reject the depiction.

The careful analyses in terms of CDA can help social media consumers raise their awareness of how news is manipulated in social media as the media discourse. In this regard, van Dijk (2006, pp. 359-383) argues since manipulation is a discursive process that requires further theoretical analysis. Many CDA analysts argue that the literature on media discourse and CDA indicate some studies about media discourse ranging from ethnicity and racism in the media, power relations, and hegemony in the media. Some other lines of studies even 
further address the relationship between the political media discourse and different patterns of hegemony.

This particular study explores the depiction of $\mathrm{ABC}$ and $\mathrm{BBC}$ during the invasion of Timor Leste in the past, mostly in relation to the Portuguese and Indonesia's presence in the territory during the period of Portuguese colony, Indonesia's entrance into the country (December 1975), the UN-endorsed referendum (1999), up to the present day. It is crucial to note that many parts of the history of Timor Leste during such a period have been neglected. Presumably, this is the reason why many (if not most) news resources depict Indonesia's presence in the country during such a period more negatively while Portuguese presence is depicted less negatively. As such, Indonesia has been seen as to 'enjoy' international sanctions, boycotts, or resolutions related to human rights. Hence, probing the reality of these claims and counterclaims in social media-particularly the ones presented by $\mathrm{ABC}$ and $\mathrm{BBC}$ is critical for understanding the truth of history.

\section{REVIEW OF LITERATURE}

News discourses play a very crucial role in changing or even shaping people's opinions about the events around them under discussion. In news resources, events are often represented, not as they should in reality. More often, they are represented in a way that the news resources want them to be (Xie, 2018, pp. 399-403). In other words, events are not always described as the way they are in real contexts. Instead, they go through the journalistic process and practices, which involve linguistic re-contextualization. After such manipulation, one single point may be depicted differently in different news resources, which contain no longer similar attitudes and ideologies. In such, points may be worded in different linguistic devices that are utilized to influence the readers' views of the events.

As Fowler (1991, p. 101) states, the news is not only a value-free reflection of facts. That is, anything the news writer says or writes about the world is articulated from a particular ideological position. As such, as van Dijk (1998, pp. 126-128) argues, news reports signify an established category of media discourse that requires a distinct method of structural analysis. It includes what van Dijk calls lexical choice, nominalization, and passivization. In Billig's view (2008, pp. 783-800), in CDA, the concept of nominalization, along with passivization, has important ideological functions such as deleting agency and reifying processes. Although nominalization will reveal the hidden ideology, he suggests critical analysts not do it in isolation. Thus, nominalization and passivization should be taken seriously in a standard way of writing a critical analysis. 
In their book Manufacturing Consent: The Political Economy of the Mass Media (1988), Herman and Chomsky introduced the Propaganda Model which "is concerned with exploring the relationship between ideology, communicative power, and social class interests" and "offers an institutional critique of mass media behavior" (in Klaehn \& Mullen, 2010, pp. 1023). Herman and Chomsky state that one of the major functions of media is their propaganda function. By propaganda, it is meant that "most of the news content is oriented toward social reproduction, i.e., the continuation of the capitalist class system, especially in its neoliberal form. This means that information is usually framed within the parameters of elite interests and certain topics and ideas tend to be excluded".

Mass media in general and newspapers, in particular, have also received the attention of many critical discourse analysis (CDA) practitioners to resist the power of newspapers in manipulating and influencing people's ideas in a way that is in favor of the elite of the society. According to Fairclough, this dimension has two facets: institutional process, that is editorial procedures and discourse processes (changes the text go-through in production and consumption). For Fairclough, "discourse practice straddles the division between society and culture on the one hand, and discourse, language and text on the other" (1995b, p. 58-60).

In his discussion about the socio-cognitive approach, van Dijk states that CDA integrates the various linguistic theories and approaches in producing a social and discursive process to "highlight the assumptions made by the more powerful on the less powerful". His sociocognitive approach attempts to link cognitive theories and approaches with linguistics. He proclaims that critical discourse studies are a critical 'perspective', 'position' or 'attitude' within the multidisciplinary approach as it intends to shed light on covert ideologies in the social practice. As such, he proposes a triangulation of the interrelationship among 'discourse', 'cognitive' and 'society' (van Dijk, 2009, pp. 62-86). This triangulation emphasizes the cognitive phenomena which are connected to the discourse structure and ways in which social inequality, domination, and ideologies occur. In efforts of discovering the 'social representations', 'attitudes' and 'ideologies' of social actors, the connection between the structure of discourse and the structure of society should be viewed (see also: van Dijk, 1998, pp. 126-128). In another discussion, van Dijk also points out that a certain group's domination (in his discussion, the white) leads to social inequality, racism and domination in certain countries (2009, pp. 62-86). Moreover, the top-down model in CDA is focused as discourse reveals the typical form of injustice in society (see also: Fairclough, 1995a, pp. 23-26). 
Every ideological representation is accompanied by experiences of a person, which is referred to as models. Van Dijk (1987, pp. 161-196) also claims that models represent personal experiences such as particular information about each event or action which is processed in short-term memory. In other words, models are parallel to cognitive functions as they observe the thinking of a person and personal knowledge that one possesses. Models are uniquely formed as they hold the ability to control experiences of a social actor (van Dijk, 1995, pp. 47-142) as well as being influenced by the cognitive process of other member groups in society. In relation to this, it is perceived that models are the primary unit which controls the various acts of human life as multiple ideologies are discovered.

In a similar manner, this present study uses the above mentioned (1987, 1995, 1998, 2006, and 2009) van Dijk's CDA models and frameworks - supported with some other CDA and other linguistic theories - to illuminate the history of Portuguese and Indonesia's presence in Timor Leste in the past as one major issue that received significant attention from $\mathrm{ABC}$ and $\mathrm{BBC}$ news resources. Thus, the main research question in this study is "How ideological depictions manifest themselves in the discourse of $\mathrm{ABC}$ and $\mathrm{BBC}$ dealing with the presence of Portuguese and Indonesia in Timor Leste?" The discussion first gives a short background of history (see: Introduction) then the method of the study-including framework and data collection procedures are provided (see: Methodology). In turn, CDA analysis will discuss the selected statements as the major discursive strategies found in the news reports on the history based on several van Djik's (1987, 1995, 1998, 2006, and 2009) models and frameworks. Finally, some general conclusions and implications based on the results of the study will be discussed.

Van Dijk's discussion about the theory of ideology also manifests in his very influential framework, which is known as van Dijk's 'ideological square' or van Dijk's 'conceptual square' (van Dijk, 2000, p. 44). In such framework, he formulates the four principles which enable hidden ideological analysis in expressing various ideological statements. They are (1) Emphasize positive things about 'Us'; (2) Emphasize negative things about 'Them'; (3) Deemphasize negative things about 'Us'; and (4) De-emphasize positive things about 'Them'. These four angles are also considered as playing a vital role in a broader contextual strategy of "positive self-presentation" and "negative other-presentation". Self-presentation displays the individual's action as a member of the group while firmly expressing various ideological notions. Positive self-representation emphasizes individuals' positive behavior as in saying positive things about 'Us' and saying negative things about 'Them'. This positive stance is an abstract characteristic of group conflicts and as the interaction pattern opposes the other 
groups. While the negative other-presentation depicts that no negative saying should be directed to 'Us', no positive saying should be directed to 'Them' (Van Dijk, 2000, p. 44). This implies that the term 'Us' always refers to positive saying and beliefs in a social context while the term 'Them' refers to negativity, condemnation and other negative stances.

\section{METHOD}

A descriptive-analytic method of research was utilized in this study, and the corpus was analyzed in order to see whether the discourse of the two social media editorials promotes any ideological orientations towards the content of the news on the historical presence of Portuguese (for more than four centuries) and Indonesia (for about 24 years) in Timor Leste (also known as East Timor).

In order to examine the representation of the two countries' presence in Timor Leste during the history, some statements selected from various related $\mathrm{ABC}$ and $\mathrm{BBC}$ editorials were analyzed. They were statements about (1) Portuguese Colony of East Timor, (2) Indonesia's Invasion, (3) Cemetery Massacre in 1991, and (4) Independence through UNbacked Referendum. Related statements were taken from the two social news resources published during the periods of the two countries' presence. The main rationale behind the selection was the two resources' popularity in releasing news about Timor Leste at the international scale and their widespread consumption. The editorials were downloaded from the official online sites of these news resources of the two companies.

Van Dijk (1987, 1995, 1998, 2005, 2006, and 2009)'s models of CDA were chosen for analyzing the linguistic features of the corpus. The description of the analyzed linguistic features is capable of depicting the dominant ways of demonstrating the social actors engaged in the issues under discussion. The statements selected were analyzed at the levels of discursive features of (a) lexical choice, (b) nominalization, (c) passivization, and (d) overcompleteness. In analyzing these structural discursive features of the statements, other potential theories are used to support van Dijk's models.

\section{RESULTS AND DISCUSSIONS}

Based on van Djik (1987, 1995, 1998, 2005, 2006, and 2009)'s models, related statements in each of the editorials were analyzed at the levels of the four above mentioned discursive features. In more details, each of the statements related to the four parts of the history of Timor Leste ([1] Portuguese Colony of East Timor, [2] Indonesia's Invasion, [3] Cemetery Massacre in 1991, and [4] Independence through UN-backed Referendum) are 
discussed hereunder. In order to make an easy difference between text and data, the data under analysis are typed in italic.

\section{Portuguese Colony of East Timor}

In van Dijk's view, the lexical choices and vocabularies in the media are very crucial because the nouns, adjectives, verbs, and adverbs chosen for making any statements can stress and transmit the mental images of society (see also: Richardson, 2007, p. 47). When telling about Portuguese presence in the past in Timor Leste (then East Timor), for example, ABC (2006, pp. 1-2) uses the term the former Portuguese colony (see also: ABC, 2009, pp. 1-2). In ABC (2009, pp. 1-2), however, the use of this phrase is initiated with Indonesian troops invade which leaves a sense that there are two different things. It feels that Portuguese presence in the past was acceptable by the local people while the Indonesian presence was not. In order to make the statement more negative for Indonesia, it is followed by the next statement. Around 100,000 people die from fighting, disease and starvation during the 24year occupation. Using almost similar wording, $\mathrm{ABC}$ (2012, pp. 1-2) writes Up to 183,000 people die from fighting, disease and starvation during the 24-year bloody occupation. While the number of death is 183,000 (instead of Around 100,000) the use of the phrase bloody occupation can be felt as leaving more negative sense.

A little differently, BBC (1999, pp. 1-2) uses the term the former colonial power to call its presence in East Timor. The use of this phrase leaves a little more positive sense compared to the former Portuguese colony used by $\mathrm{ABC}$. The use of this phrase becomes further positive as it is followed by a statement that East Timor is still recognized by the United Nations as the legal administrator of East Timor. This positive sense about Portuguese presence is even further stressed with a statement that The Portuguese public's strong feelings about East Timor partly result from guilt. --- but the guilt resulting from Portugal's undignified exit from Timor in 1975.

Also differently, BBC (2002, pp. 1-2) writes After more than 450 years as East Timor's colonial power and following a revolution at home, Portugal withdraws from East Timor. Soon afterwards Indonesia invades. There is a process of nominalization in this statement. That is, instead of using the phrase "colonizing East Timor for more than 450 years", BBC uses the phrase more than 450 years as East Timor's colonial power (for the use of the term nominalization, see: Leech, 2006, p. 69). As a result, this statement leaves at least three senses. First, Portuguese colonized East Timor for 450 years. Second, Portuguese left East Timor due to a domestic (Portuguese) revolution (for Portuguese withdrawal from East 
Timor, see also: BBC, 2013, pp. 1-3). Third, not long after such withdrawal, Indonesia invaded.

While in terms of lexical choice, the ABC uses the word 'colony' to make the statement about Portuguese presence, the word 'invade'; 'occupation'; and 'bloody occupation' are used to state Indonesia's presence in East Timor. While so, BBC uses two different words to make a statement about Portuguese withdrawal from East Timor, 'exit' and 'withdraw'. While in van Dijk's (1998, pp. 126-128) view the choice of such words is one of the discursive features that are capable of shedding light on covert ideologies in the social practice, the choices are capable of affecting the readers' conceptual knowledge which -in Evans' (2007, pp. 123-124) view-is externalized via language. Another discursive feature is made by BBC (2002, pp. 1-2) that uses nominalization to state Portuguese colonization over East Timor.

\section{Indonesia's Invasion}

In making the statement about Indonesia's invasion in East Timor, ABC (2009a, pp. 1-3) writes in December 1975: Indonesian troops invade the former Portuguese colony of East Timor. The word 'invade' is also used in ABC (2012, pp. 1-2) in the exactly similar phrase. A little differently, another ABC (2009b, pp. 1-2) news resource writes occupying Indonesian forces opened fire on a group of mourners in a cemetery. When measured in terms of lexical choice as one of the discursive features proposed by van Dijk's (1998, pp. 126-128), the word 'invade' in phrase Indonesian troops invade and the word 'occupy' in phrase occupying Indonesian discursively bring different cognition. Simply put, the word 'occupy' may leave a milder impression than the word 'invade'.

Using a similar word 'invade' BBC (1999, pp. 1-3) statement is even capable of leaving a deeper sense in Roberts' discussion titled "East Timor: The View from Portugal”. In his discussion, Roberts writes, Indonesian forces invaded just as Portugal was poised to grant the territory independence. The use of the word 'invade' in the phrase Indonesian forces invaded above should be just similar to the one used by either $\mathrm{ABC}$ or $\mathrm{BBC}$ in many ways. However, since the phrase is followed by the phrase just as Portugal was poised to grant the territory independence, the word 'invade' can now be felt as being much more serious. This might be the reason why in Billig's view (2008, pp. 783-800), although lexical choice, nominalization, and passivization will reveal the hidden ideology, critical analysts should not do it in isolation. Thus, lexical choice, nominalization and passivization should be taken seriously in a standard way of writing critical analysis (by including other parts as a whole). 
Other than using the word 'invade' in its statements (BBC, 2013, pp. 1-2), BBC also uses the word 'annex' in another statement (see: BBC, 2002, pp. 1-3). It reads 1976: Indonesia annexes East Timor. About 200,000 are killed in violence and the famine that follow. In view of lexical choice as proposed by van Dijk (1998, pp. 126-128), the use of this particular word can also leave a more serious sense. That is, the word 'annex' itself can mean 'seize'. The use of this word can even leave a more serious or 'worse' sense as it is in BBC (2002, pp. 1-3) followed with the next statement About 200,000 are killed in violence and the famine that follow. In such a combination, the word 'annex' seems to be translated into "the death of the 200,000 people". Again, this might be the reason that Billig (2008, pp. 783-800) suggests analyzing "lexical choice" in terms of CDA by including other parts as a whole.

\section{Cemetery Massacre in 1991}

The focus of the statements in this part of the discussion is what van Dijk calls the 'nominalization' of some 'verbs' and 'the number' of the victims in the event of the massacre that took place in 1991. While the event is popularly known as the '1991 massacre' both $\mathrm{ABC}$ and $\mathrm{BBC}$ write differently in terms of both the number of death and the way they nominalize the killing. In its editorial titled "East Timorese Mark $15^{\text {th }}$ Anniversary of Santa Cruz Massacre", for example, ABC (2006, pp. 1-2), writes Santa Cruz massacre, when Indonesian troops fired on a memorial procession killing more than 250 people. In all, 271 East Timorese are known to have died, while a further 250 are missing, believed dead, and 382 were wounded. First, in the statement, the fired on a memorial procession is used as the nominalization instead of 'shot the crowd'. Besides, in terms of lexical choice, the use of the words in the phrase fired on a memorial procession is much milder than 'shot the crowd' or 'fired the crowd'.

Secondly, the number of the victims is stated as more than 250 people but then continued differently with 271 East Timorese are known to have died but then again further continued with a further 250 are missing, believed dead and still further continued with and 382 were wounded. In such statement, the number of the death ' 250 people' is confused or mixed up with the other bigger numbers which might be intended - as what van Dijk (2009, pp. 62-86) calls - to emphasize "the cognitive phenomena which are connected to the discourse structure and ways in which social inequality, domination, and ideologies occur". In fact, in a former editorial titled "East Timor Massacre May Have been Solved” ABC (2009, pp. 1-2) writes victims of the 1991 Santa Cruz massacre, where occupying Indonesian forces opened fire on a group of mourners in a cemetery. More than 100 people were reportedly killed, but no 
bodies have ever been found. It can be seen that the number of death stated by ABC (2006, pp. 1-2) and the one stated by $\mathrm{ABC}$ (2009, pp. 1-2) are very different.

Differences in terms of nominalization and the number of the death are also found in BBC (1999, pp. 1-2; 2000, pp. 1-3; 2002, pp. 1-2; 2013, pp. 1-2). In its editorial titled “Timorese Remember Cemetery Massacre”, BBC (1999, pp. 1-2) writes Over 200 people were killed when Indonesian government soldiers opened fire during a peaceful protest in the cemetery on 12 November 1991, although an official Indonesian commission put the death toll at 50. In that statement, passive voice Over 200 people were killed is used instead of active voice "Indonesian soldiers killed over 200 people". This passivization is followed by although an official Indonesian commission put the death toll at 50 (see also: BBC, 2000, pp. 1-3; BBC, 2013, pp. 1-2; and BBC, 2002, pp. 1-2 where they write killing more than 100 people). Here, the process of passivization should have been able to put the statement into a milder sense. However, the use of the words 'over' and 'although' is also capable of putting the statement into a juxtaposition which at the same time leave the readers - in terms of socio-cognitive as proposed by van Dijk (2009, pp. 62-86)-have different ideological depiction about who Indonesia is and who (East) Timor (Leste) is (see also: Leech, 2006, p. $80)$.

\section{Independence through UN-Backed Referendum}

In its editorial titled "Timorese Mark $15^{\text {th }}$ Anniversary of Santa Cruz Massacre", ABC (2006, pp. 1-2) writes East Timor achieved full independence in 2002, four years after Indonesia relinquished control of the territory following a UN-sponsored self-determination ballot. Almost similarly, ABC (2009, pp. 1-2) writes August 30, 1999: Timorese vote 78.5 percent to 21.5 percent in favor of independence from Indonesia in a United Nations-backed referendum (with exactly similar the editorial found in: ABC, 2012, pp. 1-2). Although the idea in the two statements is that Timorese achieved its independence through a UN-backed referendum, the lexical choice is potentially different. That is the use of the word relinquished in the phrase four years after Indonesia relinquished control of the territory (in ABC, 2006, pp. 1-2) is capable of leaving a sense that it is Indonesia's 'intention' to 'hand over' the control of the territory. Differently, the use of the phrase Timorese vote 78.5 percent to 21.5 percent in favor of independence from Indonesia might leave a sense that it is 'the result of the vote' that makes Indonesia 'hand over' the control of East Timor. This mightas van Dijk (1998, pp. 126-128) states - be the phenomena related to the discourse structure 
and ways in which social inequality, domination, and ideologies occur that should be triangulated (see also: van Dijk, 2009, pp. 62-86).

Also differently, in its editorial titled "Timeline: East Timor 1975 to 2002" BBC (2002, pp. 1-2) writes that in 1999: 30 Aug: Nearly 99\% turn out for East Timor independence vote. 4 Sep: Election result shows $78.5 \%$ of East Timorese voted for independence from Indonesia. 20 Sep: United Nations peacekeeping-troops arrive.26 Oct: The United Nations Transitional Administration in East Timor (UNTAET) officially takes charge. In the above statement, with the details of the dates of the events, it is clear that the vote (August 30, 1999) was attended by $99 \%$ of Timorese. Five days later (September 4, 1991), the result of the election showed that $78.5 \%$ of the Timorese voted for independence from Indonesia. Surprisingly, based on this BBC (2002, pp. 1-2) editorial, it is only on September 20 (1999) that United Nations peacekeeping-troops arrive and only on October 26 (1999) that The United Nations Transitional Administration in East Timor (UNTAET) officially takes charge. Such details can-based on van Dijk's view - be seen as an 'overcompleteness' of the statement. That is because the details can raise a question whether the United Nations backed the referendum (by attending it on the spot or from the UN Office in the United States) or it is the result of the referendum that is backed up. This is something that, in terms of CDA, needs to be clarified because this UN-backed referendum has been seen as part of the rebuilding East Timor and has been stated as one of the UN's biggest success stories (see: BBC, 1999b, pp. 1-2). It has also been stated that For decades, Portugal has lobbied tirelessly in the UN, the European Union, and other international forums to persuade other governments to back their campaign against Indonesia's brutal occupation of East Timor (BBC, 1999a, pp. 1-2). In terms of 'overcompleteness' this statement also leads to a sense that it is Portugal who was successful in lobbying the UN that leads to East Timor's independence.

\section{CONCLUSION}

The findings of the present study on the depiction of Timor Leste $\mathrm{ABC}$ and $\mathrm{BBC}$ newsresource editorials are in line with some van Dijk (1987, 1995, 1998, 2005, 2006, and 2009)'s models. While in view of CDA, both $\mathrm{ABC}$ and $\mathrm{BBC}$ editorials themselves are different in terms of the effects they bring to readers' understanding, in terms of lexical choice, nominalization, passivizasion, and overcompleteness, many statements made by both $\mathrm{ABC}$ and BBC potentially lead to different social cognitive perceptions. Such differences are also potential to lead to more negative views to the readers about 24-years Indonesia's presence in East Timor and less negative views about Portuguese colonization for more than four 
centuries (for the period of Portuguese colonization, see: ABC, 2007, pp. 1-3). In other words, the lexical choice, nominalization, passivizasion, and overcompleteness in many $\mathrm{ABC}$ and BBC's statements are potential to lead the readers' perception to more negative manners of Indonesia's presence as the major source of threat for the Timorese people. On the contrary, the statements about the long colonization of Portuguese are capable of leading the readers' perception to less negative manners of Portuguese presence in Timor Leste.

In terms of van Dijk's 'ideological square' or van Dijk's 'conceptual square' many of $\mathrm{ABC}$ and $\mathrm{BBC}$ 's statements are potential to lead the readers' perception into dichotomy of 'Us' and 'Them' or also popularly known as building the 'in-group' and 'out-group' (see: van Dijk, 2000, p. 44). In this particular study, 'Us' can be linked to the ABC and BBC which are less negative in making statements about Portuguese and 'Them' can be linked to Indonesia which is depicted as more negative in both $\mathrm{ABC}$ and $\mathrm{BBC}$ 's various editorials. In

The analysis in this present study of the $\mathrm{ABC}$ and $\mathrm{BBC}$ news resource editorials on the history of Timor Leste also supports Fairclough's (1995a) viewpoint about finding different layers and interfaces within media discourse by using textual analysis, discursive analysis as well as social analysis which will result in examining power relations and ideologies. Besides, the findings are also in line with van Dijk's (1995) viewpoints about discourse analysis as ideology analysis. All in all, however, the findings of this study are based on proposed CDA theories.

\section{Acknowledgment}

I would like to express his sincere gratitude to the Rector of Universitas Wijaya Kusuma Surabaya (UWKS), the Dean of the faculty, and the Head of the English Education Department for their supports that make this research paper possible. My thanks also go to my colleagues, who supported me by supplying the difficult documents needed for sufficient data for analysis.

\section{REFERENCES}

Australia Broadcasting Corporation. (2006). East Timorese mark 15th anniversary of Santa Cruz massacre. ABC. Retrieved from https://www.abc.net.au/news/2006-11-12/etimorese-mark-15th-anniversary-of-santa-cruz/1307574

Australia Broadcasting Corporation. (2007). East Timor split on language. ABC. Retrieved from https://www.abc.net.au/news/2007-07-13/east-timor-split-on-language/2502380 
Australia Broadcasting Corporation. (2009a). Invasion to independence in East Timor". ABC. Retrieved from https://www.abc.net.au/news/2009-08-30/invasion-to-independence-ineast-timor/1409756

Australia Broadcasting Corporation. (2009b). East Timor massacre may have been solved. ABC. Retrieved from https://www.abc.net.au/news/2009-04-02/east-timor-massacremystery-may-have-been-solved/1639238

Australia Broadcasting Corporation. (2012). East Timor celebrates independence anniversary". Retrieved from https://www.abc.net.au/news/2012-05-20/east-timorcelebrates-independence-anniversary/4021968

Billig, M. (2008). The language of critical discourse analysis: The case of nominalization. Discourse \& Society, 19(6), pp. 783-800. Retrieved from https://journals.sagepub.com/doi/pdf/10.1177/0957926508095894

British Broadcasting Corporation. (1999a). East Timor: The view from Portugal by Lisbon correspondent Alison Roberts". BBC. Retrieved from http://news.bbc.co.uk/2/hi/europe/301656.stm

British Broadcasting Corporation. (1999b). Timorese remember cemetery massacre". BBC. Retrieved from http://news.bbc.co.uk/2/hi/asia-pacific/517133.stm

British Broadcasting Corporation. (2000a). Wahid apologise for Timor vilence. Retrieved from http://news.bbc.co.uk/2/hi/asia-pacific/660498.stm

British Broadcasting Corporation. (2002). Timeline: East Timor 1975 to 2002. BBC. Retrieved from http://news.bbc.co.uk/2/hi/asia-pacific/903657.stm

British Broadcasting Corporation. (2013) East Timor profile: Overview. BBC. Retrieved from https://www.bbc.com/news/world-asia-pacific-14952878

Evans, V. (2007). A glossary of cognitive linguistics. Edinburgh: Edinburgh University Press Ltd.

Fairclough, N. (1995a). Critical discourse analysis: The critical study of language. London: Longman.

Fairclough, N. (1995b). Media discourse. London: Edward Arnold.

Ferguson, R. (1998) Representing race: Ideology, identity and the media. London: Arnold Publishers.

Fowler, R. (1991). Language and the news: Discourse and ideology in the press. London: Routledge.

Herman, E. \& Chomsky, N. (1988). Manufacturing consent. NY: Pantheon Books.

Klaehn, J. \& Mullen, A. (2010). The propaganda model and sociology: Understanding the media and society. Sociology Faculty Publications. 5, pp. 10-23. Retrieved from http://scholars.wlu.ca/soci_faculty/5

Leech, G. (2006). A glossary of English grammar. Edinburgh: Edinburgh University Press Ltd.

Richardson, J.E. (2007). Analyzing newspapers. Basingstoke: Palgrave Macmillan.

van Dijk, T.A. (1987). Episodic models in discourse processing. In R. Horowitz \& S.J. Samuels, (Eds.), Comprehensing oral and written language, (pp.161-196). New York: Academic Press. 
van Dijk, T.A. (1995). Discourse analysis as ideology analysis. Language and Peace. 10, pp. 47-142.

van Dijk, T.A. (1998). Ideology: A multidisciplinary approach. London: SAGE Publications.

van Dijk, T.A. (2000). Ideology and discourse: A multidisciplinary introduction. Barcelona: Pompeu Fabra University.

van Dijk, T.A. (2005). Introduction to social semiotics. London: Routledge.

van Dijk, T.A. (2006). Discourse and manipulation. Discourse and Society, 17(3), pp. 359383. https://doi.org/10.1177/0957926506060250.

van Dijk, T.A. (2009). Critical discourse studies: A sociocognitive approach", In Wodak and Meyer [Eds.] Methods of critical discourse analysis (pp. 62-85). London: SAGE.

Wilkins, K.G. (1997). Middle eastern women in western eyes. London: Greenwood Publishing Group Inc.

Xie, Q. (2018). Critical discourse analysis of news discourse. Theory and Practice in Language Studies, 8(4), pp. 399-403, doi: http://dx.doi.org/10.17507/tpls.0804.06 